\title{
The Theme of Alienation in the Major Novels of Doris Lessing
}

\author{
Narendra Kumar Singh ${ }^{{ }^{*}}$, Dr. Chhaya Jain ${ }^{2}$ \\ ${ }^{1}$ Research Scholar, C.S.J.M. University, Kanpur, Uttar Pradesh \\ ${ }^{2}$ Asso.Prof. Dept.of English, V.S.S.D.College, Kanpur, Uttar Pradesh
}

*Corresponding Author: Narendra Kumar Singh, Research Scholar, C.S.J.M. University, Kanpur, Uttar Pradesh

\begin{abstract}
This paper aims to conduct a detailed thematic analysis of Doris Lessing's major novels. The term alienation is currently used to describe objectively observable state of separateness occurring in human group. An older usages viewed alienation as a subjective, an individual condition. It is defined variously in different eras. It depends on the ideologies and classificatory system widespread at the time. People, who are alienated, will often reject loved ones or society and feel distant. Alienation, a sociological concept developed by several classical and contemporary theorists is "A condition in social relationship reflected by a low degree of integration or common values and a high degree of distance or isolation between individuals." In short, the alienation is the inconsistency between man and attitude. Such inconsistency can be frequently seen in the novels of Lessing.
\end{abstract}

Many writers have made significant contribution on the theme of alienation. A lot of research work has been done on the very theme with reference to different poets, dramatists and fiction writers but the theme of alienation and estrangement in the novels of Doris Lessing is yet to be explored. So the present paper is an effort to analyze the isolation and its impact (estrangement) in the major novels of Doris Lessing.

Keywords: Fiction, Narrative, Alienation, Psychological Isolation

\section{INTRODUCTION}

Doris May Lessing (22 October 1919 -17 November 2013) was a British novelist, poet, playwright, biographer and short story writer. A recipient of the Nobel Prize in Literature Lessing was the oldest person ever to become a Nobel Laureate in Literature, at the age of 88. She wrote across a range of genres and detailed the conflict between man and man moreover man himself. In this paper an attempt will be made to highlight her few novels in the light of the theme of alienation. Alienation is most often represented in literature as the psychological isolation of an individual from society or community. In a volume of Bloom's literary terms, Shakespeare's Hamlet is described as the "Supreme Literary" portrait of alienation, while noting that, some may argue for Achilles in Iliad. So as Lessing's characters 'Ben Lovatt' in Ben in The World, 'Mary Turner' in The Grass is Singing, 'Anna Wulf' in The Golden Notebook, 'Martha' in Martha and Quest and in A Proper Marriage etc can be described as displaying the seeds of alienation.

\section{ANALYSIS}

Although the concept of alienation has a popular place in the analysis of contemporary life, the idea of alienation remains an ambiguous concept with elusive meanings, the following variants being very common: Meaninglessness, Powerlessness, Self- alienation, Cultural estrangement and Alienation from work. Present- day writers have used the term differently in various ways. Many writers regard it as a purely psychological concept. Others insist that alienation is also an economic or political or sociological or ethical concept. Much has so far been written about communism, feminism in the novels of Doris Lessing but scanty attention has been paid by the critics to this aspect of her novels in the light of the theme of alienation. In this paper, an attempt will be made to investigate her novels in the light of the theme of alienation. As the author has gone through the major novels of Doris Lessing, and found that most of Lessing's characters are alienated figures. 


\section{DISCUSSION}

Alienation, a sociological concept developed by several classical and contemporary theorists is: "A condition in social relationship reflected by a low degree of integration or common values and a high degree of distance or isolation between individuals." In short, the alienation in the inconsistency between man and attitude. Such inconsistency is frequently seen in the novels of Lessing.

Lessing's novels are reflection of her own ironical life. Because of it the theme of alienation runs all around in them and can be traced in the various characters of her novels. She was victimized by the tragedies in her family. She had to leave school at the age of fourteen. At fifteen she had to work as a nurse maid. She worked hard and earned family livelihood that embittered her soul and made her alienated from the family and parental relationship. The pangs of parental alienation can be very well explored in her novel The Fifth Child and its sequel Ben in the World. The character 'Ben Lovett' experiences family as an engine of hatred and rejection.

We find Lessing's writings intolerable not because she is world- weary or pessimist but she seems taking pleasure in pointing out drawbacks of human behaviour and insanity. In her autobiography Under My Skin we can see the beginning of an inner alienation as she left her school and worked as nursemaid, shorthand typist and also as telephone operator. She soon got married to her first husband but the marriage could not continue long.

Doris Lessing is an interesting writer with ambitious personality who is deeply involved with the ups and downs of thoughts, emotions, feelings and culture of her time. She has impressively depicted alienation and its impact on the characters. Her chief concern with regard to the theme of alienation in her novels is mainly the continuous problem of man-woman relationship or parent-child relationship or brother-sister relationship and individual-society relationship. In the novel The Grass is Singing Mary Turner a self confident, independent young white woman became dependent and frustrated after marrying a poor white farmer and stabbed to death by her black servant. The Golden Notebook deals with the theme of fragmentation. Briefing for a Descent into Hell is a fascinating book about a man who is supposedly mad. In Martha Quest, the central character noticed discrepancies between the words people speak and their behaviour and thereafter she begins to feel displaced, unhappy and alienated. A Proper Marriage illustrates ironically the gap between her personal desire and the compelling power of marital constraints. The fifth child describes the change in the happy life of a married couple, which occurs as a consequence of the birth of Ben, their fifth child .Memoirs of a Survivor, is a story of teenage girl who is compelled to live in the so called protection of elders. In Ben in the World, Ben is estranged from his family and goes out to find his own ways.

\section{CONCLUSION}

Most of the characters in the novels of Doris Lessing are alienated figures. We may notice that Mary Turner in The Grass is Singhing becomes depressed and frustrated. In The Golden Notebook, Ana Wulf suffers from mental breakdown. In Briefing for a Descent into Hell, Charles Watkins becomes an amnesiac patient. In Martha Quest, Martha feels displaced, unhappy and alienated. In A Proper Marriage, the reader comes to realize the protagonist's in explicable act of self-sabotage. In The Fifth Child the arrival of the fifth child brings the change in the happy life of the married couple and at the end Ben is estranged.

Thus, almost all characters in her novels are alienated figures. They are estranged from either morality or society or self. It is this pathetic alienation from morality or society or self that forms a significant part of Lessing's artistic vision.

\section{REFERENCES}

[1] The Grass Is Singing. London: Flamingo, 1993.

[2] The Golden Notebook. London: Flamingo, 1993.

[3] Briefing for a Descent into Hell. London: Flamingo, 1993.

[4] Martha Quest. London: Flamingo, 1993.

[5] A Proper Marriage. London: Flamingo, 1993.

[6] The Fifth Child. London: Flamingo, 1993.

[7] Ben in the World. London: Flamingo, 1993. 


\section{AUTHORS' BIOGRAPHY}

Narendra kumar Sing, a postgraduate from Dr. Bhimrao Ambedkar University, Agra. At present is a research fellow at C.S.J.M University Kanpur, Uttar Pradesh.

Dr. Chhaya Jain is an Associate professor at V.S.S.D.College, Kanpur and Convener of Research at C.S.J.M.University, Kanpur. She has supervised more than eight theses and has contributed to a wide range of research papers.

Citation: Narendra Kumar Singh, Dr. Chhaya Jain. "The Theme of Alienation in the Major Novels of Doris Lessing" International Journal on Studies in English Language and Literature (IJSELL), vol 6, no. 1, 2018, pp. 40-42. doi:http://dx.doi.org/10.20431/2347-3134.0601006.

Copyright: () 2018 Authors. This is an open-access article distributed under the terms of the Creative Commons Attribution License, which permits unrestricted use, distribution, and reproduction in any medium, provided the original author and source are credited. 